8. Мухаметзянов Р.Н., Соколов Е.П., Шлёнкин С.И. и др. Строение рифейских природных резервуаров Куюмбинского и Терско-Камовского участков Юрубчено-Тохомской зоны нефтегазонакопления // Геология нефти и газа. 2003. №4. C.39-45.

9. Шахновский И.М., Копылова О.Ю. Формирование месторождений нефти и газа, связанных с зонами перерывов в осадконакоплении // Геология нефти и газа. 1999. №5-6. C.22-27.

10. Чернова Л.С. Литогенетическая модель нетрадиционных карбонатных коллекторов рифея Юрубчено-Тохомской зоны (Восточная Сибирь) // Нетрадиционные коллекторы нефти, газа и природных битумов. Проблемы их освоения: Материалы науч. конф. Казань, 2005. С.327-330.

11. Сахибгареев Р.С. Привнос органического вещества в рифогенные известняки в процессе их доломитизации как причина сохранения коллекторов на больших глубинах // Закономерности размещения и критерии прогноза глубоких и сверхглубоких залежей нефти и газа. Л., 1982. C.122-133.

12. Арабаджи Е.М., Страхов П.Н. История формирования пустотного пространства в карбонатных отложениях Калинового месторождения // Геология, геофизика и разработка нефтяных месторождений. 1995. №5. С.15-17.

13. Коробов А.Д., Коробова Л.А. Гидротермальные процессы в погребённых палеорифтах Западной Сибири и их роль в доломитизации известняков и насыщении пород фундамента нефтью // Геология нефти и газа. 2005. №3. C.37-46.

14. Пустыльников А.М., Вакуленко Л.Г. Происхождение и формы выделения кремнезёма в рифейских отложениях Байкитской антеклизы (Сибирская платформа) в связи с проблемой формирования трещинно-каверновых коллекторов // Геология и геофизика. 1997. Т.38, №12. С.19621967.

15. Гришин М.П., Старосельчев В.С., Сурков В.С. и др. Мегакомплексы и глубинная структура земной коры нефтегазоносных провинций Сибирской платформы. М., 1987. $132 \mathrm{c}$.

УДК 551.761(470.4/5):567

\section{ЗОНАЛЬНАЯ СХЕМА ТРИАСА ЕВРОПЕЙСКОЙ РОССИИ ПО ИХТИОФАУНЕ}

\section{М.Г. Миних, А.В. Миних}

Научно-исследовательский институт естественных наук Саратовского государственного университета,

отделение геологии

E-mail: MinihMG@info.sgu.ru

Впервые предложена зональная схема нижне- и среднетриасовых разнофрациальных отложений Европейской России по ихтиофауне. Она разработана на основе ихтиофаунистических комплексов и группировок и базируется на последовательности эволюционного развития двоякодышащих и акуловых, с привлечением данных по лучеперым рыбам. Уточнена зональная схема верхнепермских отложений по ихтиофауне. Показано распределение рыб в триасе Восточно-Европейской платформы.
16. Эикин В.Ю. Гидротермальные изменения карбонатных пород около хрусталеносных жил // Зап. Всесоюз. минералог. о-ва. 1963. Ч.ХСІІ, вып.1. С.3-14.

17. Эикин В.Ю. Об источниках минералообразующих компонентов на примере одного из хрусталеносных месторождений Приполярного Урала // Зап. Всесоюз. минералог. о-ва. 1964. Ч.ХСІІІ, вып.6. С.672-681.

18. Бочкарёв А.И. Об образовании кварцевых тел и хрустальных гнёзд в карбонатных породах // Зап. Ленингр. горного ин-та. 1965. T.XLIX, вып.2. С.139-148.

19. Соколов Б.А., Мазор Ю.Р. Нефтегазоносность бассейнов древних платформ и трапповый магматизм // Вестн. Моск. ун-та. Сер.4, Геология. 1980. № 6. С.53-59.

20. Конторович А.Э., Хоменко А.В. Теоретические основы прогноза нефтегазоносности осадочных бассейнов с интенсивным проявлением траппового магматизма // Геология и геофизика. 2001. Т.42, №11-12. С.1764-1773.

21. Коробов А.Д. Гидротермальный литогенез в областях наземного вулканизма: Автореф. дис. ... д-ра геол.-мин. наук. М., 1995. 44 с.

22. Соколов Б.А., Абля Э.А. Флюидодинамическая модель нефтегазообразования. М., $1999.76 \mathrm{c}$.

23. Готтих Р.П., Писоикий Б.И. Роль эпитермальных флюидов в первичной миграции углеводородов в осадочном чехле Сибирской платформы // Первичная миграция и нефтегазоносность осадочных бассейнов. М., 1988. С.4756.

24. Мигурский А.В., Старосельцев В.С. Зоны разломов естественные насосы природных флюидов // Отеч. геология. 2000. №1. С.56-59.

25. Коробов А.Д., Коробова Л.А., Киняева С.И. Гидротермальные процессы в палеорифтах Западной Сибири и их роль в формировании жильных ловушек УВ доюрского комплекса Шаимского района // Геология, геофизика и разработка нефтяных и газовых месторождений. 2004. №12. C.63-72.

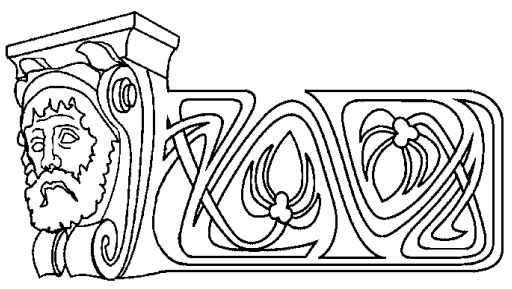

Triassic Zonal Scheme of European Russia on Ichthyofauna M.G. Minikh, A.V. Minikh

A zonal ichthyofaunal stratigraphic scheme for different facies deposits from the Lower and Middle Triassic of European Russia is proposed for the first time. The scheme has been elaborated on ichthyofaunal complexes and groups with use of evolutionary trends among dipnoans, elasmobranchians and actinopterigians. Upper Permian zonal scheme on ichthyofauna is also clarified. Distribution of fishes in Triassic of Eastern-European platform is shown. 
Континентальные, прибрежно-морские и лагунные пестроцветные и красноцветные толщи триасового возраста занимают на территории Европейской России большие пространства. Они широко развиты в пределах Северного и Южного Приуралья, Московской, Мезенской, Печорской и Прикаспийской синеклиз, в Вятско-Камской впадине и на юго-востоке Воронежской и ВолгоУральской антеклиз. Особенностью этих образований является их фациальная и литологическая изменчивость, невыдержанность в пространстве и относительно слабая палеонтологическая охарактеризованность. Ведущей палеонтологической группой при расчленении континентальных разрезов верхней перми и триаса издавна считались наземные позвоночные. По ним уже в первой половине прошлого века И.А. Ефремовым [1] была разработана первая схема расчленения верхнепермских (в прежнем понимании) и триасовых отложений. В ее основу была заложена этапность развития фауны тетрапод. Схема неоднократно дополнялась и уточнялась [2], ее последний на данное время вариант опубликован палеонтологами Палеонтологического института РАН [3].

Остатки позднепермских и триасовых рыб в виде зубов и ихтиодорулитов акуловых, зубных пластин и костей черепа двоякодышащих, костей краниального скелета заурихтисов были известны давно, но систематические сборы и изучение их было начато около сорока лет назад. Детальные монографические исследования остатков этих групп рыб позволили использовать их для решения ряда стратиграфических задач [4-13].

В последние годы были выявлены таксоны рыб, характеризующие как терминальные позднепермские отложения, так и раннетриасовые, проведено уточнение таксономического разнообразия ранне- и среднетриасовой ихтиофауны, показана эволюционная природа развития ихтиофаунистических последовательностей с рубежа перми и триаса до окончания среднетриасовой эпохи в пределах Восточно-Европейской платформы. Авторами данной статьи были детально обследованы на предмет поисков и изучения ископаемых костей рыб пограничные отложения верхней перми и нижнего триаса Московской синеклизы и Волго-Уральской ан- теклизы. Одни разрезы, заключающие этот стратиграфический интервал в континентальных фациях и содержащие ихтиофауну, были известны и ранее [14-16], другие открыты в последние годы [17]. Новый материал по ископаемым рыбам, полученный сотрудниками различных геологических организаций (В.Р. Лозовским из Московского геолого-разведочного университета, И.В.Новиковым, А.Г. Сенниковым, В.К. Голубевым и В.В. Булановым из Палеонтологического института РАН, В.П. Твердохлебовым и М.В.Сурковым из Научно-исследовательского института естественных наук Саратовского государственного университета), также был передан авторам настоящей статьи. Исследования всех известных на данное время материалов по ихтиофауне поздней перми и триаса позволили уточнить или выявить новые данные по биостратиграфии вмещающих их отложений.

В результате созданы предпосылки для уточнения ранее разработанной по рыбам зональной шкалы верхнего отдела пермской системы Европейской России и выявления ее смыкаемости с впервые создаваемой провинциальной зональной ихтиофаунистической шкалой триаса.

Вятский ярус татарского отдела ранее был охарактеризован ихтиофаунистической зоной Тoyemia blumentalis с двумя субзонами [18]. В последние годы значительно пополнился материал по верхней из них - субзоне Toyemia blumentalis - Isadia aristoviensis. B частности, поступили образцы с ископаемыми остатками рыб от А.Г. Сенникова из открытого им в 1999 г. позднепермского местонахождения Гороховец во Владимирской области [17]. Из них нами были определены зубы и чешуи Isadia aristoviensis A.Minich, чешуи, премаксилла и другие покровные кости черепа Toyemia blumentalis A.Minich, плавниковые шипы и кожные бляшки Geryonichthys ?longus A.Minich, кость крыши черепа и чешуи Mutovinia stella Minich, a также зубы хрящевого ганоида Saurichthys $s p$., т.е. формы рода, всесветно распространенного в триасовом периоде. По нашему мнению, стратиграфическому уровню этой толщи соответствуют отложения в известном местонахождении Вязники Владимирской области [2]. Отсюда из ранних сборов Б.П.Вьюш- 
кова нами были определены позднепермские таксоны рыб Geryonichthys sp., Xenosynecho$d u s$ sp. и триасовый космополит Saurichthys $s p$., а по сборам А.Г. Сенникова и В.К. Голубева в 2003 г. - фрагмент крупного ихтиодорулита ?Geryonichthys sp., покровная кость черепа Mutovinia stella Minich, чешуи Toyemia blumentalis A.Minich и ?Isadia sp., a также чешуя нового продвинутого вида Mutovinia sennikovi (А. Миних, в печати). Основываясь на данных по ихтиофауне, можно утверждать, что в осевой зоне Московской синеклизы перерыв в осадконакоплении на границе перми и триаса был небольшим. Здесь присутствуют отложения, переходные от вятского яруса верхней перми к индскому ярусу нижнего триаса: в них впервые появляется сугубо триасовый род Saurichthys (представитель мезокайнозойского надотряда Chondrostei) и новый вид Mutovinia.

Значительно южнее, в частности, в местонахождениях вятского возраста Пронькино и Боевая Гора в Оренбургской области [19], появляется триасовый вид двоякодышащей рыбы Gnathorhiza otschevi Minich. Последний факт позволяет предположить, возможно, более молодой возраст слоев, вмещающих рыб, чем считалось ранее.

Основываясь на последних данных, можно сделать вывод, что вятский ярус охарактеризован тремя ихтиофаунистическими комплексами, а не двумя, как мы ранее полагали [18]. Самый ранний комплекс включает рыб Toyemia blumentalis A.Minich, Mutovinia stella Minich, Strelnia certa A.Minich, Isadia aristoviensis A.Minich, Geryonichthys longus A.Minich и G. burchardi A.Minich и характерен для нижней части вятского яруса. В среднем ихтиокомплексе появляется Gnathorhiza tatarica Minich, а в верхнем - Gnathorhiza otschevi Minich, Mutovinia sennikovi A.Minich, Boreolepis tatarica Esin и Saurichthys $s p$.

Из триасовых отложений Европейской России к настоящему времени изучены представители акуловых, двоякодышащих и лучеперых рыб, принадлежащие двум классам - Chondrichthyes и Osteichthyes, достаточно представительный материал по которым был сконцентрирован в коллекциях Научно-исследовательского института естественных наук Саратовского государственного университета за последние сорок лет. Как уже отмечалось ранее $[13,20]$, руководящей группой для триаса исследуемой территории являются двоякодышащие рыбы (Dipnoi), по которым выявлено два крупных этапа в эволюции, охарактеризованных родами Gnathorhiza и Ceratodus. Гнаторизы известны в миpe c позднего карбона по ранний триас включительно, охватывая, возможно, и самые низы среднего триаса. Цератоды появляются в середине нижнего триаса, сосуществуют с гнаторизами в течение федоровского и, как выяснилось недавно [12], гамского времени раннего триаса, а также в низах среднего триаса, и живут поныне. Эти роды дали название двум суперихтиокомлексам - гнаторизовому и цератодовому.

Ранний этап, охарактеризованный гнаторизовым суперихтиокомплексом, включает один ихтиокомплекс - ветлужский с тремя группировками. Поздний этап, охарактеризованный цератодовым суперихтиокомплексом, объединяет два ихтиокомплекса: яренский, с тремя группировками в южном триасовом поле и с двумя группировками - в северном, и среднетриасовый, подразделяющийся на группировки пока только на юге.

Гнаторизовый суперихтиокомплекс. Ветлужский ихтиокомплекс характеризует индский и нижнюю часть оленёкского яруса нижнего триаса, что соответствует четырем горизонтам ветлужского надгоризонта: вохминскому, рыбинскому, слудкинскому и усть-мыльскому. Комплекс представлен: дипноями Gnathorhiza lozovskii Minich, Gn. otschevi Minich, Gn. triassica triassica Minich, Gn. triassica beresnikiensis Minich, акулами Hybodus spasskiensis A.Minich, H. maximi A.Minich, Lissodus volgensis A.Minich и лучеперыми Saurichthys obrutschevi A.Minich, $S$. proximus A.Minich, S. tertius A.Minich, $S$. eximius A.Minich, $S$. sp., Blomolepis vetlugensis Selesneva, Bl. sp. и Evenkia sp. (см. рисунок на вклейке 1). Руководящей формой здесь является Gnathorhiza lozovskii, а не Gnathorhiza triassica Minich, как это считалось ранее, так как один из подвидов триассики, а именно Gn. triassica beresnikiensis Minich встречается и в более поздних отложениях.

В составе ветлужского ихтиокомплекса выделяются три ихтиофаунистические группировки: ранневетлужская, средневетлужская и березниковская. 
Ранневетлужская группировка характерна для вохминского горизонта и его возрастных аналогов. Кроме руководящего таксона для всего комплекса - Gnathorhiza lozovskii - она включает руководящий таксон для группировки - Blomolepis vetlugensis, а также Bl. sp., Gnathorhiza otschevi, Hybodus spasskiensis, H. sp., Lissodus sp., Evenkia sp. и Saurichthys sp. Вблизи границы вохминского горизонта с рыбинским появляется Gnathorhiza triassica triassica. Составляющие этой группировки присутствуют в нескольких давно известных местонахождениях вохминского возраста в Московской синеклизе (Beликорецкое, Знаменское, Асташихинское). Кроме того, в последние годы чешуи рыб рода Blomolepis (определение А.В. Миних) были обнаружены А.Г. Сенниковым в песчано-гравийной линзе раннетриасового местонахождения у д.Окулово Нижегородской обл., а также были недавно найдены В.Р. Лозовским (определения рыб даны авторами настоящей статьи) в базальных слоях триаса (в недубровской пачке) на р. Кичменга (левом притоке р. Юг) на северо-востоке Московской синеклизы вместе с костями тетрапод [16]. Кости тетрапод, по определению М.А. Шишкина, принадлежат амфибии Tupilakosaurus sp. - типичной формы тупилякозавровой группировки ветлугозавровой фауны наземных позвоночных, характерной для вохминского горизонта нижнего триаса; их остатки встречены в Восточной Гренландии вместе с аммонитами индского яруса нижнего отдела триаса. Среди ископаемых рыб из недубровской пачки нами был определен еще фрагмент покровной кости черепа Saurichthys sp.

Представители ранневетлужской группировки известны и на юго-востоке ВолгоУральской антеклизы в копанской свите нижнего триаса [13].

Средневетлужская группировка характеризует рыбинский и слудкинский горизонты ветлужского надгоризонта, что в совокупности соответствует нижней части оленекского яруса нижнего триаса .

Помимо перечисленных выше таксонов (за исключением бломолеписов), составляющих ранневетлужскую группировку рыб, здесь присутствуют руководящий вид для средней группировки - Gnathorhiza triassica triassica Minich и Gnathorhiza bogdensis Minich, четыре вида заурихтисов - Saurichthys obrutschevi A.Minich, S. proximus A.Minich, $S$. tertius A.Minich, S. eximius A.Minich, акуловая рыба Lissodus volgensis A.Minich., и пока ближе не определимые брадиодонты. Рыбы, принадлежащие к этой группировке, наиболее часто встречаются в рыбинском и слудкинском горизонтах и их аналогах в Московской и Мезенской синеклизах, на юговостоке Волго-Уральской антеклизы и в Прикаспии.

Березниковская группировка с индексвидом - Gnathorhiza triassica beresnikiensis Minich - характеризует самый верхний (устьмыльский) горизонт ветлужского надгоризонта. В его составе, кроме того, отмечены Gnathorhiza lozovskii Minich, Gn. otschevi Minich, Gn. bogdensis Minich., H. maximi A.Minich., Evenkia sp. и Saurichthys sp. Типовой таксон Gnathorhiza triassica beresnikiensis, наряду с сопутствующими акулами и лучеперыми рыбами, встречается в устьмыльском горизонте в Московской синеклизе (бассейн р.Унжа, Юг и др.), в Печорской синеклизе (бассейн р.Цильма), в Мезенской синеклизе (бассейн р.Мезень), в ряде скважин на о-ве Колгуев, в Бузулукской впадине на юго-востоке Волго-Уральской антеклизы (Долгий Яр). В Южном Приуралье на этом стратиграфическом уровне двоякодышащие пока не встречены, однако здесь присутствует характерный элемент березниковской группировки - Hybodus maximi A.Minich (Красногор, Ямангулово).

\section{Цератодовый суперихтиокомплекс.} Яренский ихтиокомплекс - приурочен к верхней половине оленекского яруса и в пределах северного триасового поля включает две группировки рыб: раннеяренскую - фёдоровскую и позднеяренскую - гамскую.

Фёдоровская группировка с индексвидом Ceratodus multicristatus multicristatus Vorob. включает рыб - Gnathorhiza triassica baskunchakensis Minich, Gn. otschevi Minich, Gn. bogdensis Minich, Hybodus maximi A.Minich, Lissodus sp., Saurichthys vjuschkovi A.Minich, S. tertius A.Minich, S. sp., Evenkia sp.1 (см. рисунок на вклейке 1). Основные местонахождения данной группировки в северном триасовом поле известны в федоровском горизонте Вятско-Камской впадины в 
бассейне $p$. Вятка, в лопатинской свите Мезенской синеклизы (в бассейнах р. Вычегда и Яренга) и в верхней подсвите пижмомезенской свиты в Сафоновском прогибе (р. Пижма Мезенская).

Гамская группировка с индекс-видом Ceratodus jechartiensis Minich характеризует гамскую свиту одноименного горизонта яренского надгоризонта. Из других рыб в неё входят Ceratodus donensis Vorob. et Minich, C. multicristatus lipovensis Minich, C. gracilis Vorob, Gnathorhiza triassica baskunchakensis Minich, Gn. sp., Hybodus sp., Lissodus sp., Saurichthys sp. и Evenkia sp.1. Представители гамской группировки рыб часто встречаются в гамском горизонте в пределах Яренской впадины Мезенской синеклизы в бассейне p.Вычегда и в Вятско-Камской впадине в бассейне р.Лузы. Два таксона - Ceratodus donensis и C. gracilis - характерны как для самых верхних слоев гамского горизонта Восточно-Европейской платформы, так и для среднего триаса, где они наиболее широко распространены.

В пределах южного триасового поля - в Прикаспийской синеклизе, на юго-востоке Волго-Уральской антеклизы и на юге Предуральского краевого прогиба яренский ихтиокомплекс подразделяется на три группировки рыб: раннеяренскую - ахтубинскую, среднеяренскую - богдинскую и позднеяренскую липовскую. Руководящим видом в ахтубинской группировке, как и в федоровской на Севере, является Ceratodus multicristatus multicristatus Vorob. Кроме того, в нее входят такие виды, как Gnathorhiza bogdensis Minich, Gn. otschevi Minich, Gn. triassica baskunchakensis Minich, Hybodus spasskiensis A.Minich и Hybodus maximi A.Minich. Основное местонахождение ахтубинской группировки рыб расположено в одноименной свите на горе Большое Богдо в Прикаспийской впадине. Руководящий вид характеризует нижнюю часть разреза у с. Петропавловка в Южном Приуралье.

Для богдинской группировки характерными являются двоякодышащие рыбы Ceratodus facetidens Chab. и C. multicristatus ex gr. lipovensis Minich, присутствуют также C. ex gr. kaupi Ag. и Gnathorhiza triassica baskunchakensis Minich. Из акуловых рыб в группировку входят гибодонтиды - Hybodus spasskiensis A.Minich, H. plicatilis Ag., Acrodus dunkeri Auerb., Lissodus (?) angulatus Stensio, L. aquilus A.Minich, L. triaktis A.Minich, из лучеперых - Saurichthys sp. Представители богдинской группировки известны в Прикаспии - в нижней части богдинской свиты (Большое Богдо и скв. К-6, гл. 553 м) и в средней части петропавловской свиты в Южном Приуралье (Кзыл-Сай-2, костеносная точка 3). В северных районах Восточно-Европейской платформы основные представители данной группировки пока не обнаружены.

Липовская группировка рыб приурочена к липовской свите яренского надгоризонта на юго-востоке Воронежской антеклизы (местонахождение Донская Лука) и верхам петропавловской свиты в Южном Приуралье и на юго-востоке Волго-Уральской антеклизы (местонахождения Донгуз-9, Овраг Бехтеев, Язлав и др.). Характерным видом группировки является Ceratodus multicristatus lipovensis Minich, остальные компоненты представлены следующими видами: C. jechartiensis Minich, C. donensis Vorob. et Minich, C. gracilis Vorob, Hybodus maximi A.Minich, Lissodus triaktis A.Minich, L. (?) angulatus Stensio, Lypbalkodus gladius A.Minich, Saurichthys sp., Watsonulus sp. и Wimania sp.

Среднетриасовый ихтиокомплекс характеризует анизийский и ладинский ярусы и в пределах южного триасового поля подразделяется на две разновозрастные группировки: донгузскую и букобайскую. Более ранняя из них - донгузская группировка приурочена к донгузскому горизонту в Южном Приуралье (местонахождения Петропавловка-4, Донгуз-1, Донгуз-12, Карагачка и др.) и его аналогам в Прикаспии (местонахождения в эльтонской свите - Кок-Тау, Ази-Молла-1 и в эльтонской и низах индерской свиты в ряде скважин) [13]. Характерными для рассматриваемой группировки являются Ceratodus gracilis Vorob., C. recticristatus Vorob., C. orenburgensis Minich, Lissodus prykaspiensis A.Minich. Кроме того, в донгузскую группировку входят такие виды, как Ceratodus jechartiensis Minich, Hybodus otschevi A.Minich, H. karagachkaensis A.Minich, Lypbalkodus gladius A.Minich., Lissodus triaktis A.Minich, Saurichthys dongusensis A.Minich, Donguzodus latus A.Minich. 
Букобайская группировка характерна для букобайского горизонта в Южном Приуралье (местонахождения Букобай-5, Колтаево-3, Овраг Лысов), а также для верхней части индерской свиты и мастексайской свиты в Прикаспийской впадине (Ази-Молла-2, Кара-Бала-Кантемир и в керне ряда скважин). Группировку представляют рыбы $\mathrm{Ce}$ ratodus bucobaensis Minich, C. graclilis Vorob., C. orenburgensis Minich, Saurichthys ultimus A.Minich, Hybodus karagachkaensis A.Minich, Lissodus prykaspiensis A.Minich, Donguzodus barchanensis A.Minich и Donguzodus donatus A.Minich. Наиболее характерными из них являются Ceratodus bucobaensis Minich, Saurichthys ultimus A.Minich и Donguzodus barchanensis A.Minich.

В пределах северного триасового поля среднетриасовый ихтиокомплекс на группировки не разделяется. Он приурочен к анизийско-ладинским отложениям и представлен следующими видами: Ceratodus orenburgensis Minich, C. multicristatus lipovensis Minich, C. cf. jechartiensis Minich, а также Gnathorhiza triassica baskunchakensis Minich, Lissodus prykaspiensis A. Minich, Wimania (?) multistriata Stensio, Wimania sp., Oshia sp. и Saurichthys ultimus A.Minich. Представители среднетриасового ихтиокомплекса выявлены (за исключением гнаториз) в ряде местонахождений в Большесынинской впадине Предуральского краевого прогиба на р.Большая Сыня [20, 21]. Кроме того, по новым данным установлено присутствие представителей двоякодышащих рыб среднетриасового ихтиокомплекса на р. Луза в открытом М.Г.Минихом в 1981 г. местонахождении Ягшордын в Вятско-Камской впадине. Отсюда определены Ceratodus orenburgensis Minich, C. multicristatus lipovensis Minich и Gnathorhiza triassica baskunchakensis Minich. Примечательно, что о возможном присутствии в бассейне р. Луза среднетриасовых отложений упоминалось уже достаточно давно [22].

Верхнетриасовый ихтиокомплекс пока детально не изучен. В его составе может быть выделена лишь норийская группировка, выявленная по сборам Е.П. Карноушенко и Д.Э. Бек-Иванова из ганзинской толщи норийского яруса на о-ве Земля Вильчека архипелага Земля Франца-Иосифа. Отсюда
А.В.Миних в 1995 г. были впервые определены рыбы Saurichthys sp., ?Birgeria sp., Hybodus sp., ?Polyacrodus sp. и зубные пластинки цельноголовых рыб (Holocephalia). Часть зубных пластин была недавно определена Е.В.Поповым [23] как cf. «Eomanodon» $s p$. Вероятно, к норийским отложениям триаса приурочен колободонтид Boreichthys skolai Sel., описанный А.А.Селезневой в 1982 г. из керна одной из буровых скважин на том же о-ве Земля Вильчека (архипелаг Земля Франца-Иосифа).

Ниже предлагается зональная схема нижнего и среднего триаса Европейской России по ихтиофауне (см. рисунок на вклейке 1). Основываясь на анализе вновь полученных данных по рыбам из верхней части татарского отдела верхней перми, приводится уточненная биозональная схема вятского яруса с выделением еще одной (самой верхней) субзоны. Эта субзона, так же как и последующие триасовые субзоны и зоны, характеризующие уже ветлужский надгоризонт нижнего триаса, объединены в более крупный стратон - надзону Gnathorhiza. Выделенные в составе яренского надгоризонта нижнего триаса и в среднем триасе зоны и подзоны объединены в надзону Ceratodus.

\section{Надзона Gnathorhiza}

Зона Toyemia blumentalis

Зона характерна для вятского яруса татарского отдела верхней перми и ранее [18] разделялась на две подзоны: нижнюю Toyemia blumentalis - Strelnia certa и верхнюю - Tоуеmia blumentalis - Isadia aristoviensis. C появлением в последние годы новых данных представилась возможность более детально охарактеризовать ихтиофаунистически верхнюю часть вятского яруса и подразделить ранее существующую верхнюю подзону на две. При этом для средней подзоны оставлено прежнее название - Тоуетіа blumentalis - Isadia aristoviensis с несколько иным комплексом ихтиофауны: помимо типовых таксонов она включает двоякодышащую рыбу Gnathorhiza tatarica Minich и лучеперую Geryonichthys burchardi A.Minich. Нижняя граница средней подзоны установлена в кутулукской свите татарского отдела верхней перми у с. Новогородецкое Оренбургской обл. Новая, верхняя, подзона 
Toyemia blumentalis - Gnathorhiza otschevi Mutovinia sennikovi, занимающая как бы промежуточный (переходный) интервал между пермью и триасом, кроме типично пермских таксонов, включает такие виды рыб среди лучеперых, как Boreolepis tataricus Esin, Saurichthys sp., Mutovinia stella Minich, Geryonichthys sp. и акуловую рыбу Xenosynechodus sp., которые пока были известны только в триасе. При этом основное время развития вида Gnathorhiza otschevi Minich приходится на индский век и большую часть оленекского века раннего триаса, а род Saurichthys характерен для триаса в целом. Типовыми разрезами верхней подзоны являются разрезы терминальной перми у г.Вязники Владимирской области и разрез у с.Пронькино в Оренбургской области.

Указанные ихтиофаунистические данные могут свидетельствовать об отсутствии в этих разрезах сколько-нибудь значительного стратиграфического перерыва в осадконакоплении между пермью и триасом.

\section{Зона Gnathorhiza lozovskii - Hybodus spasskiensis}

Зона характерна для ветлужского надгоризонта нижнего триаса в объеме индского и нижней половины оленекского ярусов. Зональный комплекс характеризует ветлужский ихтиокомплекс в составе двоякодышащих рыб - Gnathorhiza otschevi Minich, Gn. lozovskii Minich, Gn. triassica triassica Minich, Gn. triassica beresnikiensis Minich и Gn. bogdensis Minich, акуловых рыб - Hybodus spasskiensis A.Minich, H. maximi A.Minich и Lissodus volgensis A.Minich, лучеперых рыб Blomolepis vetlugensis Sel., Bl. sp., Saurichthys obruchevi A.Minich, S. proximus A.Minich, $S$. tertius A.Minich, S. eximius A.Minich, $S$. sp., Pteronisculus (?) sp. и Evenkia sp. Типовые разрезы присутствуют как в пределах северного, так и южного поля развития триасовых отложений Европейской России.

В составе зоны выделяются три подзоны: нижняя - Blomolepis vetlugensis, средняя - Gnathorhiza triassica triassica и верхняя Gnathorhiza triassica beresnikiensis. Типовыми для первой подзоны являются разрезы вохминского горизонта у с. Великорецкое и Знаменское в Московской синеклизе, для средней подзоны - отложения рыбинского и слудкинского горизонтов у с. Тихвинское,
Зубовское и Бол. Слудка в Московской синеклизе, Елшанка-1 и Розжиха на юговостоке Волго-Уральской антеклизы и скв. Г-1 (Санкубай, инт. 890,1-893,6) в Прикаспийской впадине. Верхняя подзона (Gnathorhiza triassica beresnikiensis) характерна для усть-мыльского горизонта (типовые разрезы: у с. Березники в Московской синеклизе и Долгий Яр на Общем Сырте).

\section{Надзона Ceratodus}

Зона Gnathorhiza triassica baskunchakensis - Ceratodus multicristatus

Зона характеризует федоровский и гамский горизонты яренского надгоризонта, что соответствует верхней половине оленекского яруса.

В пределах южного триасового поля - в Прикаспийской впадине, на юго-востоке Волго-Уральской антеклизы и в Предуральском краевом прогибе зону характеризуют ахтубинская, богдинская и липовская группировки яренского ихтиокомплекса. Зона подразделяется на три подзоны. Нижняя из них - Ceratodus multicristatus multicristatus характеризуется сочетанием переходящих из ветлужского надгоризонта видов Gnathorhiza bogdensis Minich, Gn. otschevi Minich, Hybodus spasskiensis A.Minich и Hybodus maximi A.Minich и новых видов Gn. triassica baskunchakensis Minich и Saurichthys vjushkovi A.Minich. Типовой разрез в Прикаспийской впадине приурочен к ахтубинской свите и находится на горе Большое Богдо, а в Южном Приуралье - характеризует нижнюю часть разреза петропавловской свиты у с. Петропавловка.

Средняя подзона - Ceratodus facetidens выделяется под вопросом, соответствует богдинской свите и средней части петропавловской свиты. Зона характеризуется комплексом C. multicristatus ex gr. lipovensis Minich, C. ex gr. kaupi Ag., Gnathorhiza triassica baskunchakensis Minich, Hybodus spasskiensis A.Minich, H. plicatilis Ag., Acrodus dunkeri Auerb., Lissodus (?) angulatus Stensio, L. aquilus A.Minich, L. triaktis A.Minich и Saurichthys sp. Типовой разрез расположен в Прикаспии в нижней части богдинской свиты на горе Большое Богдо. 
Верхняя подзона - Ceratodus multicristatus lipovensis - C. jechartiensis характеризует липовскую свиту на юго-востоке Воронежской антеклизы и ее аналог - верхи петропавловской свиты в Южном Приуралье. Характерная группировка - липовская, представлена видами C. donensis Vorob. et Minich, C. gracilis Vorob., Hybodus maximi A.Minich, Lissodus triaktis A.Minich, L. (?) angulatus Stensio, Lypbalkodus gladius A.Minich, Saurichthys sp., Watsonulus sp. и Wimania $s p$. Типовой разрез находится в местонахождении Донская Лука.

В пределах северного триасового поля нижняя подзона характеризует федоровскую свиту одноименного горизонта, средняя подзона пока не выделяется, верхняя подзона соответствует гамской свите одноименного горизонта. Характерными компонентами обеих подзон являются перечисленные выше комплексы при характеристике нижней и верхней подзон соответственно на территории южного триасового поля.

\section{Зона Ceratodus recticristatus}

В пределах южного триасового поля зону характеризует донгузская группировка среднетриасового комплекса ихтиофауны, характерными элементами которой являются Ceratodus recticristatus Vorob., C. gracilis Vorob., C. orenburgensis Minich, Lissodus prykaspiensis A.Minich, Hybodus otschevi A.Minich, H. karagachkaensis A.Minich, Saurichthys dongusensis A.Minich, Donguzodus latus A.Minich, Lypbalkodus gladius A.Minich и Ceratodus jechartiensis Minich. Последние два вида появились еще в гамское время. 3она характерна для донгузского горизонта, соответствующего анизийскому и низам ладинского яруса. Типовые разрезы расположены в Южном Приуралье (Петропавловка-4, Донгуз-12 и др.), а также в Прикаспийской впадине в окрестностях оз. Индер (Кок-Тау, Ази-Молла-1).

В пределах северного триасового поля зона характеризует среднетриасовые (анизийско-ладинские) отложения в Северном Приуралье и, вероятно, среднетриасовые образования в бассейне р.Луза (Ягшордын) в Московской синеклизе. Из характерных зональных элементов ихтиофауны в Северном Приуралье присутствуют Ceratodus orenbur- gensis Minich, Lissodus prykaspiensis A.Minich и Saurichthys ultimus A.Minich. Кроме того, зональный комплекс составляют виды Wimania (?) multistriata Stensio, Wimania sp. и Oshia (?) sp. (последний родовой таксон впервые описан Е.К. Сычевской [24] из ладинско-карнийских отложений в Ферганской долине), а также двоякодышащие C. multicristatus lipovensis Minich и C. cf. jechartiensis Minich, широко распространенные в яренское время. В бассейне р.Луза зону характеризуют среднетриасовый Ceratodus orenburgensis Minich и перешедшие из яренского горизонта Gnathorhiza triassica baskunchakensis Minich и Ceratodus multicristatus lipovensis Minich.

\section{Зона Ceratodus bucobaensis - Saurichthys ultimus}

Зона характеризует букобайский горизонт, соответствующий большей части ладинского яруса (см. рисунок на вклейке 1) в Южном Приуралье, а также верхнюю часть индерской свиты и мастексайскую свиту в Прикаспии. Для зоны, помимо типовых таксонов, наиболее характерны Donguzodus barchanensis A.Minich и Donguzodus donatus A.Minich. Присутствуют и другие элементы среднетриасовой фауны рыб Ceratodus orenburgensis Minich, C. graclilis Vorob., Hybodus kara-gachkaensis A.Minich и Lissodus prykaspiensis A.Minich. Типовые разрезы - Букобай-5, Колтаево-3, Овраг Лысов на юге Предуральского краевого прогиба, а также АзиМолла-2 и Кара-Бала-Кантемир в Прикаспийской синеклизе.

$$
* * *
$$

Таким образом, выявленная ранее этапность развития триасовой ихтиофауны и закономерная смена её с рубежа перми и триаса до окончания среднетриасовой эпохи на обширной территории востока Европейской России позволяет расчленить триасовые отложения на две крупные биостратиграфические единицы - надзоны, состоящие из четырех провинциальных зон с шестью подзонами. В среднем триасе подзоны пока не выделяются. Выделенные зональные подразделения дают основу для датировок относительного возраста отложений с точностью до горизонта или его части. Достигнутая дробность расчленения вмещающих отложений по их- 
тиофауне может служить основой для дальнейшего совершенствования стратиграфии триаса Восточно-Европейской платформы и его корреляции со смежными регионами.

Работа выполнена при финансовой поддержке РФФИ (грант № 03-05-65275).

\section{Библиографический список}

1. Ефремов И.А. О стратиграфическом подразделении континентальной перми и триаса СССР по фауне наземных позвоночных // Докл. АН СССР. Нов. сер., отд. геол. 1937. T.16, №2. C.125-132.

2. Ефремов И.А., Вьюшков Б.П. Каталог местонахождений пермских и триасовых наземных позвоночных на территории СССР // Тр. Палеонтол. ин-та АН СССР. М., 1955. T.46. $156 \mathrm{c}$

3. Ивахненко М.Ф., Голубев В.Л., Губин Ю.М. и др. Пермские и триасовые тетраподы Восточной Европы // Тр. Палеонтол. ин-та АН СССР. М., 1997. 216 с.

4. Воробьёва Э.И., Миних М.Г. Опыт применения биометрии к изучению зубных пластинок цератодонтид // Палеонтол. журн. 1968. №2. С.76-87.

5. Миних М.Г. Рыбы // Стратотипический разрез баскунчакской серии нижнего триаса горы Большое Богдо. Саратов, 1972. С.48-50.

6. Миних М.Г. Триасовые двоякодышащие рыбы востока Европейской части СССР. Саратов, 1977. 96 c.

7. Миних А.В. Ихтиодорулиты и их значение для стратиграфии татарских и триасовых отложений востока европейской части СССР // Вопросы стратиграфии и палеонтологии. Саратов, 1975. Вып.1. С.29-32.

8. Миних А.В. Заурихтисы из триаса СССР// Палеонтол. журн. 1981. №1. С.105-113.

9. Миних А.В. Новые представители акуловых рода Нybodus из триаса востока европейской части СССР // Там же. 1985. №3. C.66-70.

10. Миних А.В. Заурихтисы (Saurichthyiformes) из среднего триаса Южного Приуралья // Вопросы палеонтологии: Межвуз. науч. сб. СПб., 1992. Т.Х. С.146-151.

11. Миних М.Г., Миних А.В. Расчленение триасовых отложений Восточно-Европейской платформы по ихтиофауне // Триасовые отложения Восточно-Европейской платформы. Саратов, 1985. С.44-51.

12. Миних М.Г., Миних А.В. Ихтиофауна в стратиграфии триаса севера Европейской России // Геология и минеральные ресурсы европейского северо-востока России: Материалы XIV Геолог. съезда Республики Коми: В 4 т. Сыктывкар, 2004. T.3. C.333-335.
13. Миних М.Г., Миних А.В. Ихтиофауна в корреляции разрезов триаса Южного Приуралья, Воронежской и юговостока Волго-Уральской антеклиз и Прикаспийской впадины // Недра Поволжья и Прикаспия. Саратов, 2005. Вып.42. С.35-45.

14. Блом Г.И. Каталог местонахождений фаунистических остатков в нижнетриасовых отложениях Среднего Поволжья и Прикамья. Казань, 1968. 375 с.

15. Лозовский В.P. Континентальный эталон нижнего отдела триасовой системы // Палеонтология и стратиграфия континентальных перми и триаса Северной Евразии. M., 1995. C.18-20.

16. Лозовский В.Р., Красилов В.А., Афонин Г.А. и др. О выделении новой пачки в составе вохминской свиты нижнего триаса Московской синеклизы // Бюл. РМСК по Центру и югу Русской платформы. М., 2001. Вып.3. C.151-163.

17. Сенников А.Г., Голубев В.К., Буланов В.В. и др. Богатейшее местонахождение пермских позвоночных на территории Восточной Европы // Геологические, геофизические и геохимические исследования юго-востока Русской плиты: Материалы науч. межвед. конф., 2-4 апр. 2001 г. Саратов, 2001. C.58-59.

18. Миних М.Г., Миних А.В. Стратиграфическое значение позднепермской ихтиофауны Восточно-Европейской стратотипической области. Ихтиокомплексы и зональная шкала // Верхнепермские стратотипы Поволжья: Докл. Междунар. симп., 28 авг. 1998 г. М., 1999. С.265-268.

19. Tverdokhlebov V.P., Tverdokhlebova G.I., Minikh A.V. et al. Upper Permian vertebrates and their sedimentological context in the South Urals, Russia // Earth-Science Reviews. 2005. №69. P.27-77.

20. Миних М.Г. Позднепермская и триасовая ихтиофауна Европейской России (систематика, этапы развития, стратиграфическое значение): Дис. ... д-ра геол.-минерал. наук. Саратов, 1998. 68 с.

21. Новиков И.В. Биостратиграфия континентального триаса Тимано-Североуральского региона по фауне тетрапод. М., 1994. Т.261. 139 с.

22. Лозовский В.Р., Розанов В.И., Кюнтиель М.К. Новые данные о возрасте верхней части пестроцветных триасовых отложений бассейнов рек Лузы, Вычегды и Мезени // Докл. АН СССР. 1968. Т.183, №3. С.668-671.

23. Popov E.V. A history of Elephant fishes of the genus Callorhinchus Lacepede, 1798 (Holocephali, Chimaeroidei) // First International Palaeontological Congress (IPC2002), 6-10 July, 2002. Masquarie University, N.S.W. Canberra, 2002. P.261-262.

24. Sytchevskaya E.K. Freshwater fish fauna from the Triassic of Northen Asia // Mesozoic Fishes 2. Sistematics and Fossil Record. Munchen, 1999. P.445-468. 


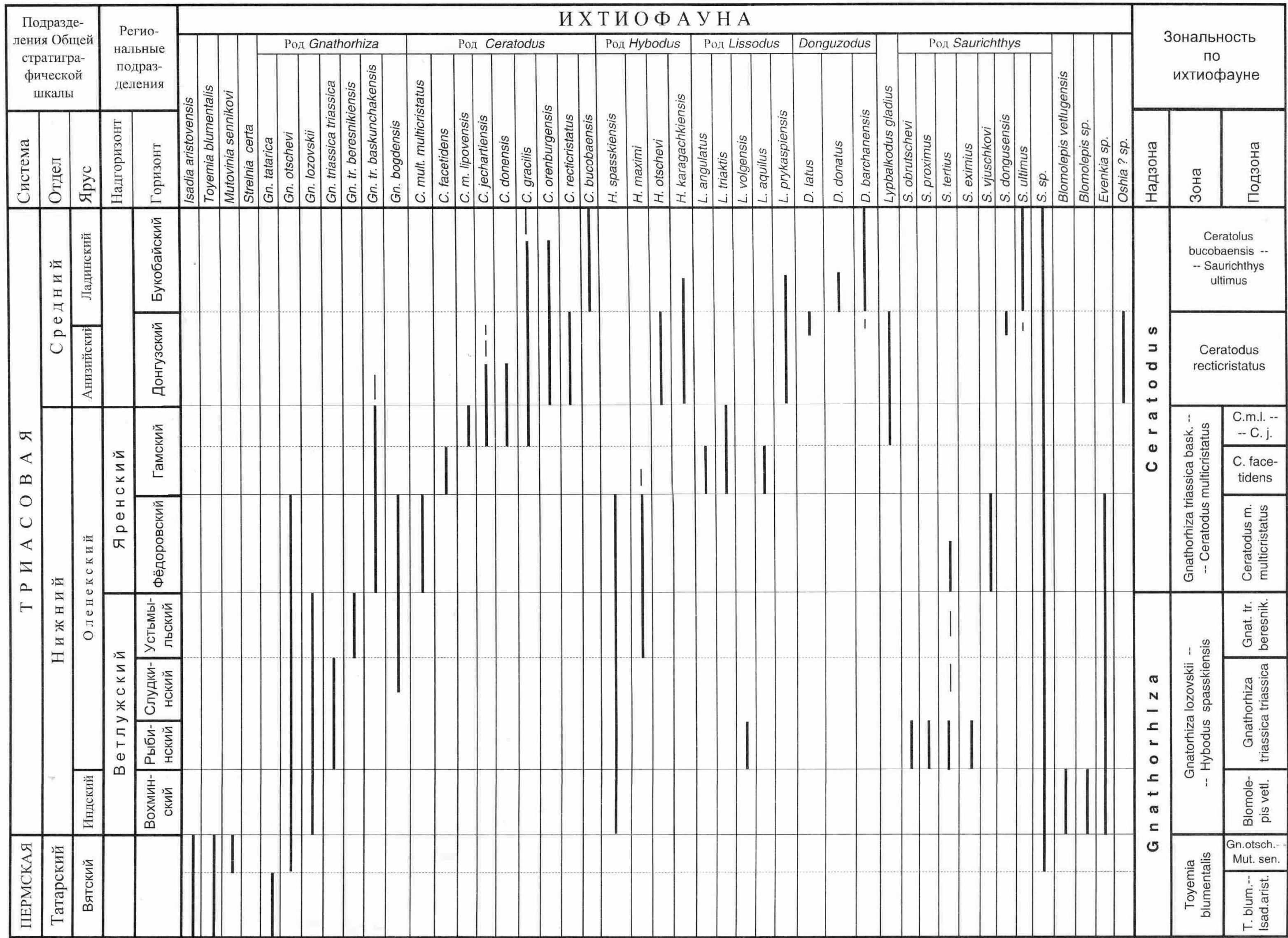

Примечание: "Gnathorhiza triassica bask." -- Gnathorhiza triassica baskunchakensis: "C. m..." -- Ceratodus multicristatus lipovensis; "C. facetidens" -- Ceratodus facetidens; "Ceratodus m. multicristatus" -- Ceratodus multicristatus multicristatus; Gnat. tr. beresnik." --- Gnathorhiza triassica beresnikiensis; "Gnathorhiza trias. triassica" -- Gnathorhiza triassica triassica; "Blomolepis vetl." "-- Blomolepis vetlugensis; "Gn. otsch. -- Mut. sen." -Gnathorhiza otschevi -- Mutovinia sennikovi; "T. blum. -- Isad. arist." -- Toyemia blumentalis -- Isadia aristovensis. 